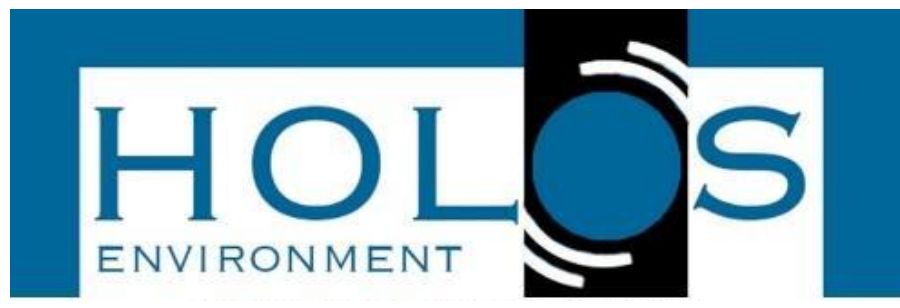

\title{
MACROFAUNA INDICATORS IN DOMESTIC SEWAGE AREAS IN LANDSCAPE A BRAZILIAN DRY TROPICAL FOREST
}

\section{INDICADORES DE MACROFAUNA EM ÁREAS DE ESGOTO DOMÉSTICO NA PAISAGEM DE UMA FLORESTA TROPICAL SECA NO BRASIL}

\author{
Iluliane Maria Gadelha de Lima1; Débora Coelho Moura²; Ailson de Lima Marques; \\ Brenda Henrique de Souza²; Regiane Farias Batista"; \\ Cássio Ricardo Gonçalves da Costa $^{3}$
}

Artigo recebido em: 20/10/2020 e aceito para publicação em: 02/02/2021.

DOI: http://doi.org/10.14295/holos.v21i2.12429

\begin{abstract}
This research sought to obtain and analyze seasonally indicators of macrofauna in areas of domestic sewage in the Caatinga. The experiment was carried out at Federal University of Campina Grande, located in the city of Campina Grande - Brazil. A of 3493 individuals were analyze seasonally indicators of macrofauna in areas of domestic sewage in the Caatinga captured from the 20 traps installed at the three sampling points and at both periods (dry and wet). The taxonomy as a bioindicator indicates that there is an intense contribution of organic material coming from the effluents. There is an exuberant diversity, but with compromised soil bioturbation, so the soil formation rate is compromised and the natural pedogenic processes interrupted or altered. The soils are being altered by the domestic effluent that provides a non-labile organic material to the fauna of the soil, and this process intensified in the wet period.
\end{abstract}

Keywords: Caatinga. Dry forest. Environment. Soil; Taxonomy.

Resumo: Esta pesquisa buscou obter e analisar indicadores sazonais da macrofauna em áreas de esgoto doméstico da Caatinga. O experimento foi conduzido na Universidade Federal de Campina Grande, localizada na cidade de Campina Grande - Brasil. Foram analisados 3.493 indivíduos sazonalmente indicadores da macrofauna em áreas de esgoto doméstico da Caatinga capturados nas 20 armadilhas instaladas nos três pontos de amostragem e em ambos os períodos (seco e úmido). A taxonomia como bioindicador indica que há uma intensa contribuição de matéria orgânica proveniente dos efluentes. A diversidade é exuberante, mas com a bioturbação do solo comprometida, a taxa de formação do solo fica comprometida e os processos pedogênicos naturais interrompidos ou alterados. Os solos estão sendo alterados pelo efluente doméstico que fornece uma matéria orgânica não lábil à fauna do solo, e esse processo se intensifica no período das chuvas.

Palavras-chave: Caatinga. Floresta seca. Meio Ambiente. Solo. Taxonomia.

\footnotetext{
1Universidade Federal da Paraíba (UFPB), João Pessoa, PB. E-mails: (iluli.correia@gmail.com, marques.ailsonl@gmail.com, regiane.2594@gmail.com)

2 Universidade Federal de Campina Grande (UFCG), Campina Grande, PB. E-mails: (debygeo@hotmail.com, brendasouza.bh@gmail.com)

3 Universidade Federal Rural do Semi-Árido (UFERSA), Mossoró, RN. E-mail: (cassioagronomoufpb@gmail.com)
} 


\section{INTRODUCTION}

The state of Paraíba, in the semi-arid northeast of Brazil, presents a diversified vegetation mosaic composed of plant species from Seasonal Forests, from the Atlantic Forest and Caatinga biome, however the Caatinga species are more dominant in this environment. In this context, knowledge and conservation of the biological biodiversity of the Caatinga is one of the greatest challenges of Brazilian science, since it is the only Brazilian endemic biome and one of the most degraded, due to the unsustainable use of its natural resources, which has caused the disappearance of species never cataloged and the emergence of high rates of extinction (LEAL et al., 2003, SOUZA et al., 2015).

All this vegetation mosaic is a reflection of the soil, this is a non-renewable resource, vital for food production and also for the global balance and functioning of ecosystems. Soil, a non-renewable resource, is vital for food production and also for the global balance and functioning of ecosystems, its food chain is organized at different levels according to the size of individuals and is fundamentally based on the relationships between microorganisms and invertebrates that live permanently or spend some stages of their development in the soil or in the litter, which are therefore the habitat of a large group of organisms that are in constant interaction and whose activities largely influence the physical and chemical properties soil (SILVEIRA et al., 2016; BRITO et al., 2016; CASTRO et al., 2016; COSTA et al., 2019; COSTA et al., 2020).

The litter consists of the material recently fallen on the surface of the soil, works basically as a conditioner, providing the necessary resources for the maintenance of the macrofauna in this environment (MARQUES et al., 2014). These organisms can be classified as macrofauna, when they have a body diameter greater than $2 \mathrm{~mm}$ or a length greater than $10 \mathrm{~mm}$; mesofauna organisms that measure between $0.2 \mathrm{~mm}$ and $2 \mathrm{~mm}$ in body width and microfauna generally with body width less than $0.2 \mathrm{~mm}$. They can also be grouped according to eating habits: phytophagous animals (consumers of plants), zoophages (predators and parasitoids of other animals), saprophages (consumers of decaying animals and vegetables), scavengers (consumers of dead animals and vegetables) and geophages (feed on soil) (CÂNDIDO et al., 2012; MOREIRA et al., 2008).

According to Moreira et al (2008) macrofauna is known as "ecosystem engineers" because it is directly linked to biophysical processes, including aggregation, thus constituting a group of organisms that affects the availability of resources for other species through changes in its habitat, from the transport and movement of the soil and creating structures 
above and within it that can remain for decades. However, the increasing rates of deforestation, degradation and loss of topsoil, which is much higher than its rate of formation, have been causing habitat loss, and thus building one of the main threats to soil biodiversity.

The soil macrofauna communities generally comprise between 15 and 18 taxonomic groups: Gastropoda, Oligochaeta, Isopoda, Arachinida, Diplopoda, Chilopoda, Blattaria, Orthoptera, Dermaptera, Hemiptera, Lepidoptera larvae, Diptera larvae, Coleoptera larvae, Coleoptera larvae, Isoptera and others. Including organisms such as earthworms, insects, myriapods and arachnids and their benefits, result mainly from the mechanical movement of the soil, increasing the aeration and redistribution of nutrients, in addition to increasing the content of organic matter in the soil profile. Thus, playing a key role in the functioning of the ecosystem, since it occupies several trophic levels within the soil food chain and affects primary production directly and indirectly. (SILVEIRA et al., 2016; CORREIA \& ANDRADE, 2008; BARROS et al., 2008).

The composition of the soil macrofauna and the knowledge of human activities on these communities is extremely important, as they are directly linked to the processes of decomposition, nutrient cycling, maintenance of the physical properties of the soil, thus being a bioindicator of soil quality, and its alteration due to the impact of anthropic activities can lead to a complete decrease in diversity and change in the functioning of the soil, these being sensitive indicators of the natural system, land use and management, thus allowing, from studies of the same, a quick assessment, easy and economical, which makes it a powerful tool in the assessment and monitoring of soil quality (BARROS et al., 2008).

In according to Barros et al., (2008) interest in assessing soil quality has been increasing, with the awareness that it is an extremely important component of the biosphere, not only for food production, but also for maintaining environmental quality. Macrofauna has been used by many scholars as an indicator of soil pollution and degradation. The same reports in his analyses that the organisms that inhabit the soil are exposed to polluting agents due to their direct dermal contact with the soil solution or by ingestion of colloidal particles of contaminated soil, being able to absorb and accumulate polluting agents .

Thus, this research sought to obtain and analyse seasonally indicators of macrofauna in areas of domestic sewage in the Caatinga. 


\section{MATERIAL AND METHODS}

\subsection{Characterization of the Study Area}

The experiment was carried out at Campus I, at the Federal University of Campina Grande, which is located in the municipality of Campina Grande-PB (Figure 1 and 2). The area is formed by a vegetation of Caatinga and Seasonal Forest species with a shrubby tree. The area is included in the scope of the Brazilian Semi-Arid, however, because it is above 500 meters above sea level, it has a Hot and Dry Tropical Climate, or sub-humid, according to Thornthwaite and Mather (1955) (FRANCISCO et al., 2015).

In addition, the altitude of 552 meters, provides temperatures of $25^{\circ} \mathrm{C}$ during the year. The relative humidity of the air is between 75 to $82 \%$. The rainy season starts in February and ends in August (LIMEIRA, 2008). The geological base is composed of magmatic and metamorphic rocks, with smooth wavy relief, and the predominant soils are of the type Luvisols, Gleysols and Fluvisols, according to Pereira et al., 2017, (Figure 3).

Figure 1 - Location of the area, from the study of the Soil Macrofauna as a Landscape Bioindicator, in Campus I, at the Federal University of Campina Grande, Campina Grande - Paraiba - Brazil

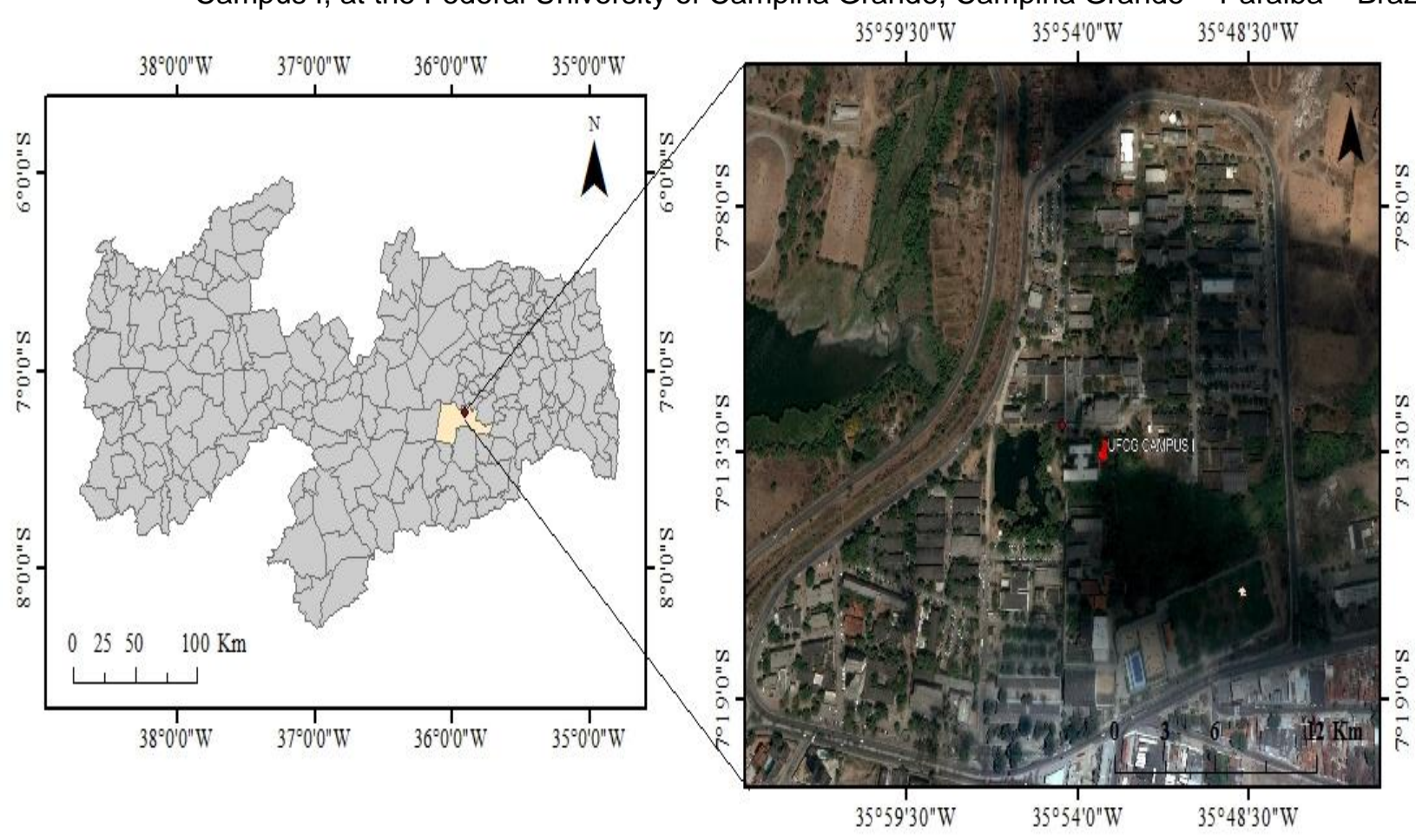


Figure 2- Soil representation map of the study areas of the Soil Macrofauna as a Landscape Bioindicator, in Campus I, at the Federal University of Campina Grande, Campina Grande - Paraiba - Brazil

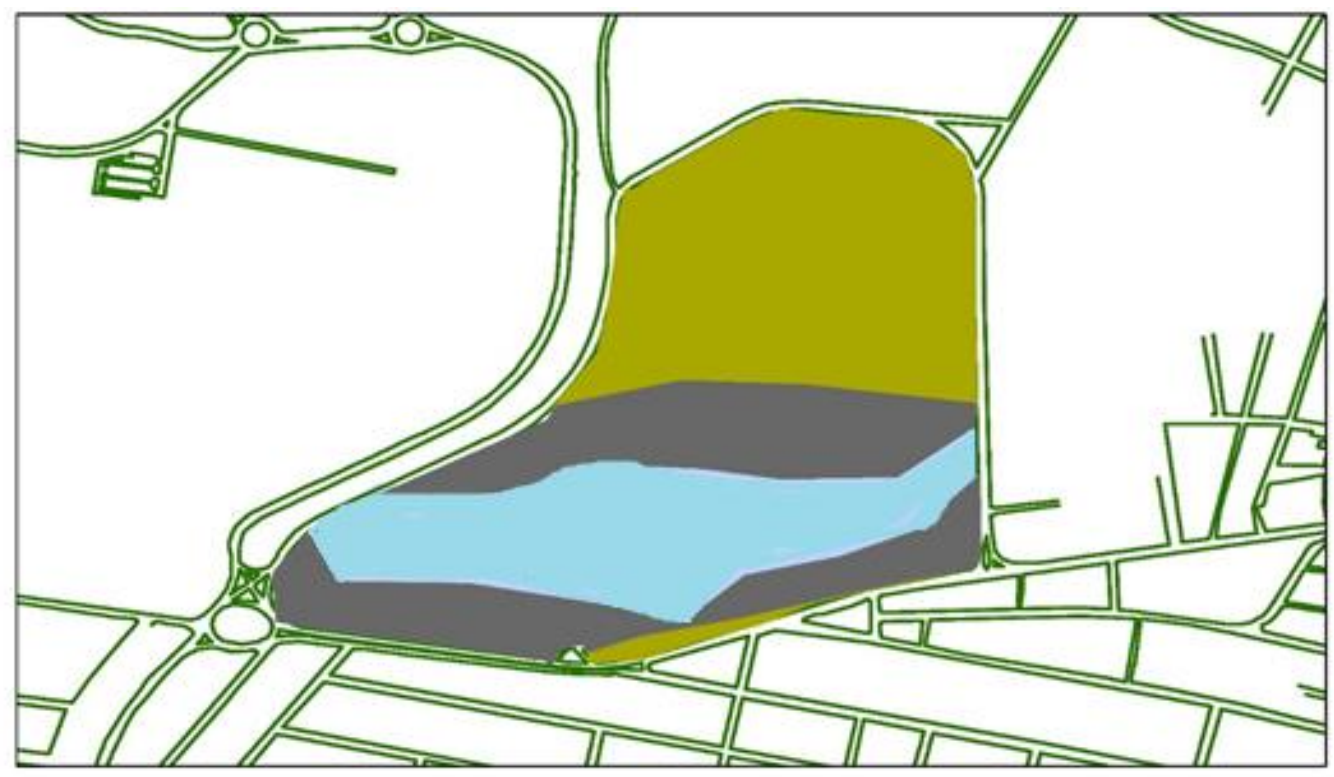

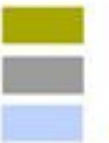
Luvisols
Gleysols
Fluvisols

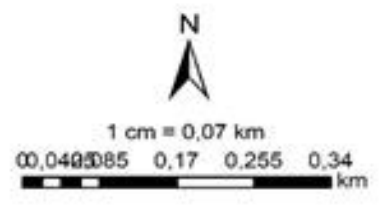

Figure 3 - Macrofauna collection areas, with predominant soils such as: Luvisols (A), Gleysols (B) and Fluvisols (C) at Campus I, at the Federal University of Campina Grande, Campina Grande Paraíba - Brazil
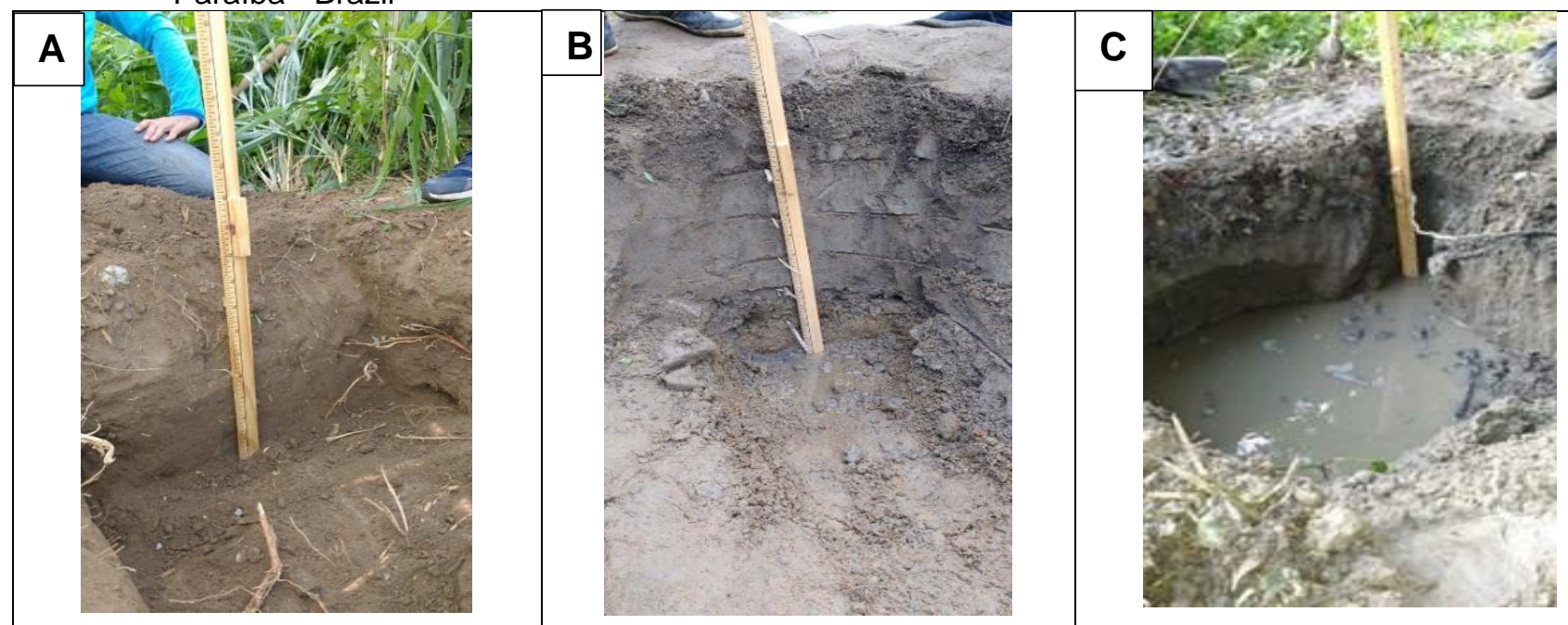


\subsection{Experiment procedures}

Every experiment and development of the project has a technical and theoretical basis in accordance with the Practical Guide to Soil Biology (DIONISIO et al., 2016) and the Manual for collecting soil macrofauna (AQUINO, 2001). The collection of soil macrofaunal was performed by pitfall type, these were you adapt to containers of polystyrene, which were arranged about $10 \mathrm{~cm}$ tall and $10 \mathrm{~cm}$ in diameter at the ground level, so that the animals to they move around, they accidentally fall into these containers. A of 3493 individuals were analyze seasonally indicators of macrofauna in areas of domestic sewage in the Caatinga captured from the 20 traps installed at the three sampling points and at both periods (dry and wet). A total of 20 traps were installed at three different points (a) urban green area in regeneration, close to the Electrical Engineering Unit; b) lake channel, near the Central Library; c) floodplain area of the domestic and industrial waste channel, close to the Sports Gym.

In each trap, a solution of approximately $100 \mathrm{ml}$ of $70 \%$ alcohol and $5 \mathrm{ml}$ of detergent was prepared at the Laboratory of Studies and Research in Geography (LAEP), Federal University of Campina Grande - UFCG/UAG/ CH, Campus I, these after being installed remained on campus for 5 days in different points of the area, sampling was carried out in the dry period from October 9 to 13, 2017, where the monthly average of precipitation was 28.7 millimeters $(\mathrm{mm})$; and in the rainy season from May 10 to 15, 2018 in the region.

The identification and counting in functional groups of orders, was held at the Laboratory of Studies and Research in Geography (LAEP), the Federal University of Campina Grande - UFCG/UAG/CH, Campus I. The insects collected were stored in $70 \%$ alcohol. The post-separated macrofauna was identified at the level of large groups (Orders) using identification keys from Barnes (1984) and Borror, and Delong (1969) and in functional groups such as Decomposers, Herbivores, Predators (HÖFER et al., 2000) and also in Engineers of the ecosystem (JONES et al., 1994; LAVELLE, 1997). The joint analysis of variance was also performed using the simple multiple comparison test of means with SkottKnott at the level of $5 \%$ error significance.

For analysis of the landscape and the data obtained, two theories of biogeography were used, the Geosystemic theory and Landscape Ecology, and the hypothetical deductive method was also used. The mapping, treatment and spatialization procedures of the results of this research were made using the software: Google Earth, QGis and ArcGIS 10, licensed 
to the Multiuser Laboratory of Information Technologies Applied to Human Sciences, at the Humanities Center of the Federal University of Campina Grande.

\section{RESULTS}

Of the 20 traps installed in the three sampling points and in the two periods (dry and wet), a total of 3493 individuals were captured. Regarding taxonomy (Table: 1 and 2), Table 1 (dry period) and Table 2 (wet period) have their distribution, and for functional groups.

It is noteworthy that the forest area did not correspond as an environment of greater diversity and number of individuals, which is linked to the strong anthropic disturbance of this environment and also dispersion of individuals to other areas due to a greater supply of organic material, but a deficit in mineralization. This is due to the inexpressive number of the Oligochaeta Haplotaxida Class (earthworms). Possibly this organic material has a complex chemical combination that affects the establishment of earthworms in the medium.

Table 1 - Taxonomy and distribution of individuals in the dry period

\begin{tabular}{lcccc}
\multicolumn{1}{c}{ Taxonomy } & Forest Area & Dry Area & Wet Area & Individuals \\
\hline Sub-order Brachycera Schiner & 1 & 10 & 9 & 20 \\
Haplotaxide Oligochaeta Class & 1 & 0 & 1 & 2 \\
Order Hymenoptera & 113 & 387 & 242 & 742 \\
Order Juliformia & 13 & 0 & 0 & 13 \\
Order Coleoptera & 7 & 63 & 61 & 124 \\
Order Orthoptera & 0 & 0 & 2 & 2 \\
Apocrite Suborder & 0 & 0 & 1 & 1 \\
Order Blattaria & 0 & 5 & 0 & 5 \\
Isopods & 0 & 30 & 1 & 31 \\
Subphylum & 16 & 73 & 16 & 105 \\
Araneae & 0 & 0 & 0 & 0 \\
Order & & & & \\
Littorinimorpha & 3 & 0 & 0 & 3 \\
Order Dermaptera & 0 & 0 & 1 & 1 \\
Stylommatophora suborder & 2 & 0 & 0 & 2 \\
Order Hemiptera & 1 & 8 & 0 & 9 \\
Order Diptera & 1 & 101 & 1 & 103 \\
Larvae & 158 & 677 & 335 & 1170 \\
Total by area & & & & \\
Number of Individuals: 1212 & & &
\end{tabular}


Table 2 - Taxonomy and distribution of individuals in the wet period.

\begin{tabular}{lcccc}
\multicolumn{1}{c}{ Taxonomy } & Forest Area & Dry Area & Wet Area & Individuals \\
\hline Sub-order Brachycera Schiner & 75 & 9 & 78 & 162 \\
Haplotaxide Oligochaeta Class & 0 & 2 & 1 & 3 \\
Order Hymenoptera & 470 & 365 & 769 & 1604 \\
Order Juliformia & 14 & 1 & 10 & 25 \\
Order Coleoptera & 8 & 36 & 45 & 89 \\
Order Orthoptera & 2 & 2 & 2 & 6 \\
Apocrite Suborder & 6 & 5 & 5 & 16 \\
Order Blattaria & 3 & 2 & 0 & 5 \\
Isopods & 8 & 33 & 10 & 51 \\
Subphylum Chelicerata & 12 & 1 & 25 & 38 \\
Araneae & & & & \\
Order Littorinimorpha & 0 & 0 & 34 & 34 \\
Order Dermaptera & 0 & 0 & 3 & 3 \\
Stylommatophora suborder & 0 & 0 & 31 & 31 \\
Order Hemiptera & 1 & 1 & 0 & 2 \\
Order Diptera & 0 & 0 & 0 & 0 \\
Larvae & 6 & 4 & 10 & 20 \\
Total by area & 604 & 460 & 1023 & 2087 \\
Number of Individuals: 2281 & & & & \\
\hline
\end{tabular}

When dealing with diversity, Order Hymenoptera was excluded, as in analogous works it needs to be disregarded in the creation of algebraic (graphical) and statistical data due to its significant expression which prevents the visualization of other orders in data protection. It can be seen that in the semi-arid region, the literature of the last 10 years has shown that the Order Hymenoptera (ants) is the one that stands out in the region, followed by the Order Coleoptera (Beetles), which is confirmed with the analysis of employed variance. This context was seen in this research.

The importance of the sub-order Brachycera Schiner (flies), Isopods (garden armadillo), Subphylum Chelicerata Araneae (spiders) and larvae is also emphasized. Such identifications emphasize the pollution environment in the wet period as a propagator of the multiplication conditions of these individuals. Pollution brings diverse organic material that conditions the intense action of mesofauna also activating the multiplication of beetles and garden armadillos that are engineers of the soil (ruin this organic material in the soil) and fly that seek to feed, which favors predators like spiders. The larvae signal the multiplication of this diversity and it is noteworthy here its greatest number in the dry period, which is linked to the incubation period of these species with potential hatching in the humid period. 
The largest number of herbivores is evident at the expense of fewer engineers, decomposers and detractors. This finding corroborates the environment in which they are located, which is configured by the greater contribution of decomposable or not decomposable organic matter, but not mineralized, possibly due to the complex chemical arrangement of domestic tributaries.

\section{DISCUSSION}

The diversity of soil macrofauna in the study area in both periods, a significant increase in the number of individuals in the wet period is noticeable in all taxonomy identified, which is linked to the incubation period of these species with potential hatching in the humid period. The functional groups established by BROWN et al., (2001) are based on the trophic criterion, as follows: (1) Phytophages: consume and digest living tissue from plants; (2) Omnivores: feed on organic matter of animal and vegetable origin; (3) Detritivores: feed on decomposing organic matter; (4) Geophages: feed on soil and humus; (5) Rhizophages: consume and digest tissue from plant roots; (6) Predators: feed on other living organisms, regulating their populations; (7) Parasites: feed at the expense of host organisms.

SWIFT et al., (2010), in turn, work with the concept of key functional groups and establish 10 functional groups, five of which can be applied to macroinvertebrates: (1) Herbivores (= phytophagous): consume and digest living plant tissues, including strand drills and sap suckers; (8) Ecosystem engineers: have a strong physical impact on the soil, carrying out soil transport, building structures and forming pores; (9) Litter transformers: they fragment plant debris, making it more accessible to decomposing microorganisms, or promote the growth of microorganisms in pelleted stools; (6) Predators: feed on other living organisms, regulating their populations; (10) Pests: they attack plantations, causing economic losses; (11) Pollinators: transfer of pollen between male and female flowers that guarantees the production of fruits and seeds and the reproduction of several plants.

In the samples collected before these two classifications, we can identify as herbivores ants, butterflies, cricket, bees and soldiers; engineers beetles, garden armadillos, earthworms, embuá, scissors and snails; decomposers flies and beetles and predators to snails and ants.

The bioindicator taxonomy indicates in this research that there is an intense supply of organic material coming from the sewage (that is why we have more herbivores), however this organic material is not being decomposed (fewer engineers and detractors) and 
mineralized (decomposers). There is an exuberant diversity, but with compromised bioturbation in the soil (high earthworm deficit), with that the soil formation rate is compromised and the natural pedogenic processes interrupted or altered.

In the areas of Gleysols and Fluvisols there is or will be a thickening of the A horizon to be a hystic $A$. The strong smell of sulfur at the site demonstrates this process, which is caused by water saturation (absence of oxygen in the soil) and oxidation of organic methane, releasing a sulfur-based (hydrogen sulphide) gas. It is worth mentioning a Fluvic Neossolo and a Gleissolo not located on the coast, but also influenced by thiomorphism.

In these circumstances, we have an anthropogenic action that has drastically influenced the soil. The soils are being altered by the complexity of the domestic tributary that provides non-labile organic material to the soil fauna, and this process is intensified in the wet period. It is possible to correlate the floodplain area of the domestic and industrial waste channel with a greater abundance of domestic and industrial organic material, in various stages of decomposition. These available waste products are readily mechanical vectors (domestic pests) of pathogenic organisms (bacteria and fungi) to the surrounding community

\section{CONCLUSIONS}

The diversity of the identified macrofauna presents the great biodiversity of organisms in concomitance with its most diverse functions, a remnant area of seasonal forest in recomposition. Taxonomy as a bioindicator indicates in this research that there is an intense supply of organic material coming from the sewage (that's why we have more herbivores), but this organic material is not being decomposed (fewer engineers and detractors) and mineralized (decomposers). There is an exuberant diversity, but with compromised bioturbation in the soil (high earthworm deficit), with that the soil formation rate is compromised and the natural pedogenic processes interrupted or altered.

In the areas of Gleissolos and Neossolo Flúvico there is or will be a thickening of the A horizon to be a hystic A. The strong smell of sulfur at the site demonstrates this process, which is caused by water saturation (absence of oxygen in the soil) and oxidation of organic methane, releasing a sulfur-based (hydrogen sulphide) gas. It is worth mentioning a Fluvic Neossolo and a Gleissolo not located on the coast, but also influenced by thiomorphism. 
In these circumstances, we have an anthropogenic action that has drastically influenced the soil. The soils are being altered by the complexity of the domestic tributary that provides non-labile organic material to the soil fauna, and this process is intensified in the wet period.

It is possible to correlate the floodplain area of the domestic and industrial waste channel with a greater abundance of domestic and industrial organic material, in various stages of decomposition. These available wastes are readily mechanical vectors (domestic pest) of pathogenic organisms (bacteria and fungi) to the surrounding community.

\section{REFERENCES}

ANDRADE-LIMA, D. The caatingas dominium. Revista Brasileira de Botânica, v. 4, p. 149-163, 1981.

ALBUQUERQUE, S. G.; BANDEIRA, G. R. L. Effect of thinning and slashing on forage phytomass from a caatinga Petrolina, Pernambuco, Brazil. Brazilian Agricultural Research, v. 30, n. 6, p. 885-891, 1995.

ALVES, F. I. V.; LIMA, A. R.; FIALHO, J. F. Edaphic fauna in a semiarid agro-ecosystem with 17 years of fallow. Biosphere Encyclopedia, v. 13, n. 24, p. 1-10. 2016.

https://doi.org/10.18677/EnciBio 2016B 114

BARNES, O. R. Zoology of Invertebrates. 4th.ed. Pennsylvania: Roca, p. 1179. 1984.

BARROS, Y. J. Biological indicators of soil quality in the mining and lead processing area, in the municipality of Adrianópolis (PR). Master's Dissertation presented to the Postgraduate Course in Soil Science. Curitiba, Parana- Brazil. 2008.

BERTRAND, G. Global physical landscape and geography. Curitiba: Editora UFPR, 2004. p.141-152,

BAGLIANO, R. V. Main Organisms Used as Bioindicators Reported Using Environmental Damage Assessors. Environment and Sustainability Magazine, v. 21, 2012.

BRAZIL. Brazilian Agricultural Research Corporation. Landscape ecology: concepts and potential applications in brazil. Documents 121. Planaltina, DF: EMBRAPA, 2004.

BORROR, D. J.; DELONG, D. M. Introduction to Insect Studies. São Paulo, 1969.

BRITO, M. F.; TSUJIGUSHI, B. P.; OTSUBO, A. A.; SILVA, R. F.; MERCANTE, F. M. Diversity of edaphic and epigeic fauna of invertebrates in a consortium of cassava with green

manures. Research agropec. bras. v. 51, n. 3, p. 253-260, 2016. https://doi.org/10.1590/S0100$\underline{204 \times 2016000300007}$

BROWN, G. G.; FRAGOSO, C.; BAROIS, I.; ROJAS, P.; PATRÓN, J. C.; BUENO, J.; MORENO, A. G.; LAVELLE, P.; ORDAZ, V.; RODRÍGUEZ, C. Diversity and functional role of the edaphic macrofauna in Mexican tropical ecosystems. Mexican Zoological Act, v. 1, p. 79-110, 2001. 
CASTRO, A.; TEIXEIRA. A. F. R.; SILVA, V. M.; GARCIA, P. D. G.; PAULINO, C. C. Edaphic Macrofauna in Conilon Coffee Production Systems, Sooretama, Espiríto Santo : Rainy Period. In: BRAZILIAN CONGRESS OF SOIL SCIENCE. 2016. [Anais...]. Uberlândia, Minas Gerais. 2016.

CÂNDIDO, A. K. A. A.; SILVA, N. M.; BARBOSA, D. S.; FARIAS, L. N.; SOUZA, W. P..Fauna Edáfic as Bioindicators of Environmental Quality in the Source of the São Lourenço River, Campo Verde -MT, Brazil. Environmental Engineering, v. 9, n. 1, p. 067-082, 2012.

CORREIA, M. E. F.; ANDRADE, A. G. Litter formation and nutrient cycling. In: SANTOS, G. de A.; SILVA, L. S. da; CANELLAS, L. P.; CAMARGO, F. A. O. (Ed.). Fundamentals of soil organic matter: tropical and subtropical ecosystems. 2 ed. Porto Alegre: Metrópole, p.137-158. 2008.

COSTA, C. R. G.; FRAGA, V. S.; LAMBAIS, G. R.; SOARES, K.O.; SUDDARTH, S.R.P.; MEDEIROS S.S. Chemical and Physical Quality of the Entisol in a Natural Regeneration Area in the Semiarid Region of Paraiba. Journal Of Experimental Agriculture International, v. 35, n. 2, p. 1-7. 2019. https://doi.org/10.9734/jeai/2019/v35i230202

COSTA, C. R. G.; SILVA, M. G.; CUNHA, R. S. M.; SOUSA, M. M.; LINHARES, A. C. M.; SILVA, S. S.; MARQUES, A. L.; MOURA, D. C.; BATISTA, R. F.; LIMA, J. A. M. Richness and Diversity of the Edaphic Macrofauna in a Brazilian Seasonally Dry Tropical Forest. Journal Of Experimental Agriculture International, v. 42, n. 9, p. 80-85, 2020. https://doi.org/10.9734/jeai/2020/v42i930589

EMBRAPA. Brazilian Agricultural Research Corporation. Brazilian soil classification system. 3ed. - Rio de Janeiro: EMBRAPA. 2008.

FIGUERÓ, A. S. Biogeography: dynamics and transformations of nature. São Paulo: Text Workshop. 2015.

FRANCISCO, P. R. M.; MEDEIROS, R. M. O. F.; SANTOS, D.; MATOS, R. M. Köppen and Thornthwaite Climate Classification for the State of Paraíba. Brazilian Journal of Physical Geography. v. 8, n. 4, p. 1006-1016, 2015. https://doi.org/10.5935/1984-2295.20150049

HOFER, H.; HANAGARTH, W.; GARCIA, M.; MARTIUS, C.; FRANKILIN, E. N.; ROMBKE, J.; BECK, L. Structure and function of soil fauna communities in Amazonian anthropogenic and natural ecosystems. Eur. J. Soil Boil, 37, 1-7, 2001. https://doi.org/10.1016/S1164-5563(01)01089-5

HOFFMANM, R. B.; BIRTH M. S. V.; DINIZ, A. A. Diversity of the edaphic mesofauna as a bioindicator for soil management in sand, Paraíba, Brazil. Caatinga, v. 22, n. 3, p. 121-125, 2009.

JONES, C. G.; LAWTON, J. H.; SHACHAK, M. Organisms as ecosystems

engines. Oikos, Copenhagen, v. 69, p. 373-386, 1994. https://doi.org/10.2307/3545850

LAKATOS, E. M.; MARCONI, M. A. Fundamentals of scientific methodology. 3. ed. São Paulo: Atlas, 1991.

LAVELLE, P. Diversity of soil fauna and ecosystem function. Biology International, v. 33, p. 3-16, 1996. https://doi.org/10.1016/S0065-2504(08)60007-0

LAVELLE, P. Faunal activities and soil processes: Adaptive strategies that determine ecosystem function. Adv. Ecol. Res. v. 27, p. 93-132, 1997.

LEAL, I. R., TABARELLI, M.; SILVA, J. M. C. Ecology and conservation of the

Caatinga. University Publisher, Federal University of Pernambuco, Recife, Brazil, 2003. 
LIMEIRA, T. M. S. Variability and Rain Trends in the State of Paraíba, 2008.

122p. Dissertation. (Master in Meteorology of Meso and Grande Escales) - Graduate Program in Meteorology. Federal University of Campina Grande- UFCG. Campina Grande - Brazil, 2008.

KORASAKI, V.; MORAIS, J. W.; BRAGA, R. F. Macrofauna. In: MOREIRA, F. M. S.; CARES, J. E.; ZANETTI, R.; STÜRMER, S. L. (Eds.). The soil ecosystem: components, ecological relationships and effects on plant production. Lavras: Editora da UFLA, p. 79-128, 2013.

MARQUES, D. M.; SILVA, A. B.; SILVA, L. M.; MOREIRA, A.; PINTO, G. S. Edaphic macrofauna in different vegetation coverings. Biosci. J. v. 30, n. 5, p. 1588-1597, 2014.

MOREIRA, F. M. S.; SIQUEIRA, J. O.; BRUSSAARD, L. Soil biodiversity in Brazilian ecosystems. Lavras: Ed UFLA. 2008.

METZGER, J.P What is landscape ecology?. Biota Neotropica, v. 1, n. 1, BN 00701122001 , Sep/Nov/2001. https://doi.org/10.1590/S1676-06032001000100006 . Available in Dec, 2017 from http://www.biotaneotropica.org.br/v1n12/en/fullpaper?bn00701122001+en

MOURA, D. C. Bee and Plant Community as Environmental Indicators in Forest Management Areas in the Caatinga, Northeast Brazil. In: GARIGLIO, et al. (orgs). Sustainable Use and Conservation of Caatinga Forest Resources. Brasília: Brazilian Forest Service, p. 301-314, 2010.

PEREIRA, T. M. S. Wealth and Diversity of Vegetations in Rocky Outcrops the Municipality of Esperança-PB. Monography (Monograph in Geography) - Federal University of Campina Grande - UFCG. Campina Grande. 2016.

PEREIRA, T. M. S.; MOURA, D. C.; SILVA, J. A. L.; RODRIGUES, E. M.; MELO, J. I. M. Floristic rescue of seasonal forest vegetation in the municipality of Campina Grande - PB. Rev.

Geogr. Academic. v. 11, n. 1, p. 1-10, 2017.

SILVA, M. C. S.; LIMA SOBRINHO, F. S.; SILVA, A. V.; BARROS, R. P. The use of traps type pitfall $p$ ara survey of soil fauna in soils with cultivation of Manihot esculenta Crantz and Opuntia spp in rural Arapiraca - AL. In: NORTHEASTERN CONGRESS OF BIOLOGISTS, 6., 2017. [Annals...]. p. $2446-4716$, 2017. https://doi.org/10.21472/congrebio2016.et-09-018

SILVEIRA, E. R.; PELISSARI, A.; MORAES, A.; JAMHOUR, J. Diversity and functional role of soil macrofauna in crop-livestock integration. Technical-Scientific Magazine, p. 1-15, 2016

SPSITO, E. S. Geography and Philosophy: Contribution to the teaching of geographic thought. São Paulo: EdUNESP. 2004

SOUZA, B. I., ARTIGAS, R. C., LIMA, E. R. V. Caatinga and Desertification. Mercator. v. 14, n. 1, p. 131-150, 2015. https://doi.org/10.4215/RM2015.1401.0009

SWIFT, M. J.; BIGNELL, D.; MOREIRA, F. M. de S.; HUISING, J. The inventory of biological soil biodiversity: concepts and general guidelines. In: MOREIRA, F. M.

A handbook of tropical soil biology. Londres: Routledge, 2010. p. 1015 